\title{
PENERAPAN MODEL PEMBELAJARAN KOOPERATIF TIPE JIGSAW UNTUK MENINGKATKAN PRESTASI BELAJAR FISIKA SISWA KELAS XI IPA 4 SMA NEGERI 1 SELEMADEG TAHUN PELAJARAN 2014/2015
}

\author{
Oleh \\ I Dewa Made Warnita \\ Guru Mata Pelajaran Fisika SMA Negeri 1 Selemadeg \\ dewawarnita@gmail.co.id
}

\begin{abstract}
ABSTRAK
Objek dari penelitian tindakan kelas ini adalah implementasi model pembelajaran Kooperatif Tipe Jigsaw, dan prestasi belajar fisika siswa kelas XI IPA 4 SMA Negeri 1 Selemadeg tahun pelajaran 2014/2015. Bertujuan untuk mengetahui model pembelajaran Kooperatif Tipe Jigsaw dalam meningkatkan prestasi belajar fisika siswa Kelas XI IPA 4 SMA Negeri 1 Selemadeg tahun pelajaran 2014/2015. Penelitian yang dilaksanakan di SMA Negeri 1 Selemadeg melibatkan 20 orang siswa. Sebagian besar siswa memiliki pemahaman yang kurang, hanya $30,00 \%$ yang memperoleh nilai $\geq$ KKM. Penelitian ini dilakukan 4 tahapan yakni : perencanaan tindakan, pelaksanaan tindakan, observasi/penilaian, dan refleksi yang terakomodasi dalam dua siklus pembelajaran. Metode pengumpulan data yaitu mengidentifikasi setiap jawaban dari pelaksanaan tes prestasi belajar. Data yang diperoleh dianalisis dengan menggunakan metode deskriptif kuantitatif dan kualitatif. Hasil penelitian menunjukkan bahwa setelah diterapkan pembelajaran kooperatif tipe Jigsaw terjadi peningkatan dengan capaian nilai rata-rata sebesar 81,25 dan persentase ketuntasan sebesar 85,00 yag tergolong kategori baik, maka berarti penerapan model pembelajaran kooperatif tipe Jigsaw dapat meningkatkan prestasi belajar Fisika siswa Kelas XI IPA 4 SMA Negeri 1 Selemadeg tahun pelajaran 2014/2015.
\end{abstract}

Kata kunci: Model pembelajaran kooperatif, Jigsaw, Prestasi belajar.

\begin{abstract}
The object of this classroom action research is the implementation of cooperative learning Model Jigsaw, and achievement of learning physics class XI IPA 4 SMA Negeri 1 Selemadeg the school year 2014/2015. The aim of this research is to determine the type of cooperative learning model of Jigsaw in improving student learning achievement of physics in class XI IPA 4 SMA Negeri 1 Selemadeg the school year 2014/2015. The research, conducted at SMA Negeri 1 Selemadeg involving 20 students. Most of the students have a poor understanding, only $30.00 \%$ are scored $\geq$ KKM. This research was conducted in 4 step: planning, action, observation / assessment, and reflection are accommodated in two cycles of learning. Data collection methods used were identified any answer from the implementation of the learning achievement tests that have. Then data were analyzed using descriptive quantitative and qualitative methods. The results showed that after application of Jigsaw cooperative learning, a very significant increase of the achievements of the average value of 81.25 and a percentage of 85.00 completeness classified either category, then it means that the application of Jigsaw cooperative learning model can improve students learning achievement of physics in class XI IPA 4 SMA Negeri 1 Selemadeg the school year 2014/2015.
\end{abstract}

Keywords : Cooperative learning, Jigsaw, Learning achievement.

\section{PENDAHULUAN}

Pelajaran Fisika yang mencakup fakta, konsep, prinsip atau hukum serta prosedur, yang mana dalam kegiatan pembelajarannya disesuai dengan tuntutan kompetensi yang harus dicapai siswa. Sesuai dengan tujuan fisika yakni mengamati, memahami dan 
memanfaatkan gejala-gejala alam yang melibatkan zat (materi) dan energi. Kemampuan observasi dan eksperimen ini lebih ditekankan pada melatih kemampuan berpikir dan bernalar eksperimental yang mencakup tatalaksana percobaan dengan mengenal peralatan yang digunakan dalam pengukuran (Depdiknas, 2006:4). Dari deskripsi ini, diupayakan pembelajaran menjadi lebih efektif apabila dalam pelaksanaannya guru memahami peran, fungsi dan kegunaan mata pelajaran yang diajarkan. Selain pemahaman akan hal-hal tersebut, efektif tidaknya pembelajaran ditentukan juga oleh kemampuan guru untuk merubah model pembelajaran agar sesuai dengan harapan Permen No. 41 tahun 2007 tentang Standar Proses.

Mata pelajaran Fisika sebagai mata pelajaran dalam kelompok ilmu pengetahuan dan teknologi memiliki peran yang sangat penting dalam pengembangan intelektual, sosial dan emosional siswa. Fisika sebagai mata pelajaran yang secara spesifik diajarkan di SMA, yang mana sebelumnya pada saat di SLTP Fisika tergabung dalam mata pelajaran IPA. Sampai saat ini Fisika masih dianggap mata pelajaran yang sulit dipahami siswa, membosankan, bahkan menakutkan. Anggapan ini mungkin tidak berlebihan karena mata pelajaran fisika mempunyai sifat yang abstrak, menakutkan dan tidaklah menarik di mata siswa . Pada akhirnya anggapan tersebut berpengaruh pada minat siswa dalam belajar fisika yang berdampak pada prestasi belajar siswa menjadi menurun. Dalam kompleksitas permasalahan pembelajaran fisika ini, tampaknya peran guru sebagai penyampai pengetahuan menjadi kunci utama sebagai problem solver dengan kemampuan dalam memilih dan menerapkan model pembelajaran yang efektif dalam pembelajaran fisika di sekolah.

Disamping itu konsep Fisika yang baru dipelajari siswa, berkaitan erat dengan konsep-konsep sebelumnya . Saat ini masih ditemukan adanya kesulitan yang dialami siswa dalam mempelajari konsep Fisika. Salah satu kesulitan yang dimaksud adalah pemahaman terhadap konsep Fluida Staik dan Flluida Dinamis. Akibatnya sebagian besar siswa mengalami kendala dalam menjawab soal-soal ulangan harian dan ulangan umum, yang berhubungan dengan konsep Fluida Statik dan Fluida Dinamis.

Fenomena ini dialami oleh guru selama proses pembelajaran berlangsung, seperti pada penelitian awal yang dilakukan peneliti di Kelas XI IPA 4 Semester 2 SMA Negeri 1 Selemadeg Tahun Pelajaran 2014/2015 dalam tiga kali pertemuan pembelajaran. Berdasarkan penelitian awal yang diamati peneliti bahwa siswa cendrung bersikap sangat pasif dalam pembelajaran. Apabila siswa diminta mengelaborasi kembali konsep yang telah disajikan melalui beberapa pertanyaan, sebagian besar siswa memiliki pemahaman yang kurang, hanya $30,00 \%$ (6 orang dari 20 siswa) yang memperoleh nilai $\geq$ KKM yang 
ditetapkan oleh satuan pendidikan. Jika tidak ditunjuk, mereka tidak mampu mengajukan diri untuk menjawab, menanggapi, ataupun bertanya. Ketika siswa diminta untuk menjawab pertanyaan yang diberikan guru, mereka merasa ragu dengan kemampuannya sendiri. Diinterpretasikan bahwa siswa mengalami hambatan-hambatan dari segi pemahaman dan pencapaian hasil belajar yang optimal.

Kondisi tersebut disebabkan oleh kurang sesuainya metode mengajar dan media pembelajaran yang digunakan guru. Kondisi demikian teratasi manakala guru berupaya untuk menentukan solusinya, yaitu merubah model pembelajaran konvensional yang selama ini digunakan. Salah satu model pembelajaran yang diyakini mampu mengatasi permasalahan belajar siswa tersebut adalah model pembelajaran Kooperatif tipe Jigsaw. Berdasarkan kenyataan tersebut guru sebagai peneliti mencoba menyusun sebuah alur penyelesaian masalah dan mendokumentasikannya menjadi sebuah penelitian ilmiah untuk dijadikan acuan bersama, dengan judul Penerapan Model Pembelajaran Kooperatif tipe Jigsaw untuk meningkatkan Prestasi Belajar Fisika Siswa Kelas XI IPA. 4 SMA Negeri 1 Selemadeg Tahun Pelajaran 2014/2015.

Model pembelajaran kooperatif tipe jigsaw adalah sebuah model kooperatif yang menitik beratkan kepada kerja kelompok siswa dalam bentuk kelompok kecil, seperti yang diungkapkan Lie ( 1993: 73), bahwa pembelajaran kooperatif tipe jigsaw merupakan model belajar kooperatif dengan cara siswa belajar dalam kelompok kecil yang terdiri atas empat sampai dengan enam orang secara heterogen dan siswa bekerja sama saling ketergantungan positif dan bertanggung jawab secara mandiri. Dalam model pembelajaran jigsaw, siswa memiliki banyak kesempatan untuk mengemukanakan pendapat, dan mengelolah imformasi yang didapat dan dapat meningkatkan keterampilan berkomunikasi, anggota kelompok bertanggung jawab atas keberhasilan kelompoknya dan ketuntasan bagian materi yang dipelajari, dan dapat menyampaikan kepada kelompoknya (Rusman, 2008:203).

Pada dasarnya faktor-faktor yang mempengaruhi prestasi belajar siswa dapat dibedakan menjadi dua golongan, yaitu faktor yang berasal dari dalam diri individu dan faktor yang berasal dari luar diri individu. Kedua faktor ini akan saling mendukung dan saling berinteraksi sehingga membuahkan sebuah hasil belajar (Haryanto, 2010).

\section{METODE}

Penelitian Tindakan Kelas ini dilaksanakan di kelas XI IPA 4 SMA Negeri 1 Selemadeg yang beralamat di Jalan Gelogor, Bajera, Selemadeg, Tabanan. Sebagai 
subjek penelitian adalah siswa kelas XI IPA 4 SMA Negeri 1 Selemadeg Tahun Pelajaran 2014/2015 semester 2 yang berjumlah 20 orang.

Objek penelitian ini adalah implementasi model pembelajaran Kooperatif Tipe Jigsaw sebagai variabel bebas, prestasi belajar fisika siswa kelas XI IPA 4 SMA Negeri 1 Selemadeg tahun pelajaran 2014/2015 sebagai variabel terikat.

Penelitian ini dilakukan dari bulan Januari sampai bulan Maret 2015. Penelitian ini dilaksanakan dalam 2 siklus, masing-masing siklus mencakup empat tahap yaitu perencanaan, pelaksanaan, observasi, dan refleksi, dan masing-masing siklus terdiri dari 3 kali pertemuan.

Metode pengumpulan data yang digunakan untuk mendapatkan data prestasi siswa dalam konsep fluida dikumpulkan dengan cara mengidentifikasi setiap jawaban dari pelaksanaan tes prestasi belajar yang telah dilakukan. Selanjutnya, data yang telah terkumpul diolah dengan metode analisis data deskriptif kuantitatif dan kualitatif sehingga diperoleh persentase keaktifan siswa dan persentase ketuntasan klasikal.

Untuk mengolah data kuantitatif dalam bentuk nilai rata-rata klasikal dengan menggunakan rumus sebagai berikut.

$$
\text { Nilai rata }- \text { rata }(\mathrm{Nr})=\frac{\sum \text { Nilai Perolehan Siswa }}{\sum \text { Siswa }}
$$

Untuk menentukan persentase ketuntasan klasikal (KK) dipergunakan rumus sebagai berikut.

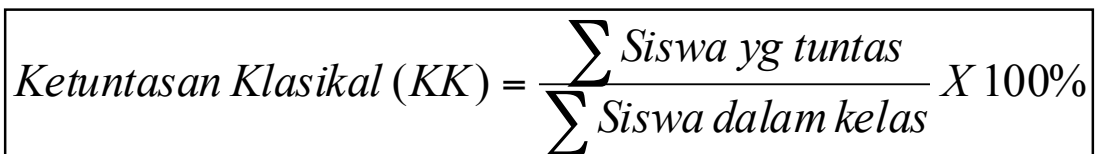

Kriteria keberhasilan penelitian tindakan kelas ini adalah apabila siswa telah mencapai nilai aspek kognitif dan psikomotorik $\geq 77$, dan apabila siswa yang mencapai ketuntasan belajar $\geq 85 \%$.

\section{HASIL DAN PEMBAHASAN}

Setelah dilaksanakan penelitian tindakan kelas selama kurang lebih 3 (tiga) bulan melalui penelitian awal/prasiklus, siklus I, dan siklus II diperoleh data sebagai berikut.

Berdasarkan data penelitian awal yang dilaksanakan dalam tiga kali pertemuan dengan menerapkan metode ceramah, diskusi dan tanya jawab, peserta didik kurang kondusif dalam mengikuti pembelajaran. Dari 20 orang siswa hanya 6 (enam) orang yang 
dapat memahami konsep Fluida Staik dan Fluida Dinamis. Hasil pengamatan dapat dilihat pada Tabel 1.

Tabel 1.Data Prestasi Belajar Siswa pada Penelitian Awal

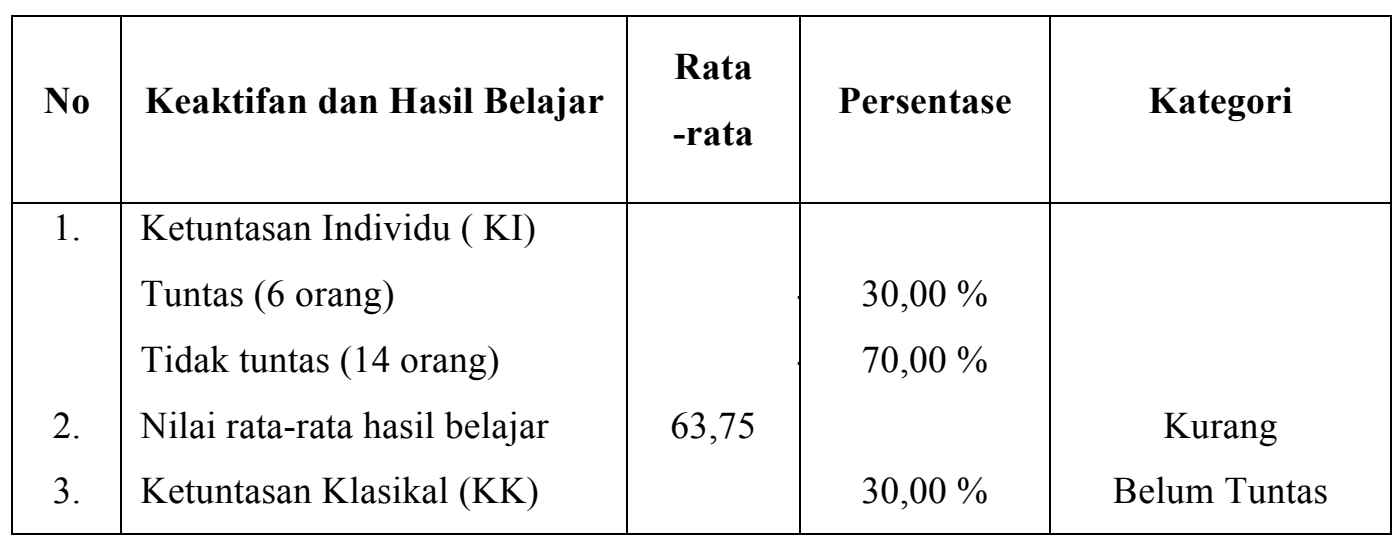

Data pada refleksi awal menunjukkan bahwa KK sebesar 30,00\% yang berarti belum memenuhi kriteria tuntas. Berdasarkan data tersebut berarti kelas XI IPA 4 SMA Negeri 1 Selemadeg Tahun Pelajaran 2014/2015 dalam pelajaran fisika menunjukkan siswa yang belum tuntas sebanyak 14 orang atau daya serap terhadap materi pembelajaran masih rendah.

Setelah dilaksanakan tindakan pada siklus I dengan menerapkan Model Pembelajaran Koperatif tipe Jigsaw diperoleh hasil prestasi belajar seperti pada Tabel 2.

Tabel 2. Data Prestasi Belajar Siswa pada Siklus I

\begin{tabular}{|c|l|c|c|c|}
\hline No & Keaktifan dan Hasil Belajar & Rerata & Persentase & Kategori \\
\hline 1. & Ketuntasan Individu ( KI) & & & \\
& Tuntas (11 orang) & & $55,00 \%$ & \\
& Tidak tuntas (9 orang) & & $45,00 \%$ & \\
2. & Nilai rata-rata hasil belajar & 70,25 & - & Cukup \\
3. & Ketuntasan Klasikal (KK) & & $55,00 \%$ & Belum Tuntas \\
\hline
\end{tabular}

Dari tabel di atas tampak nilai rerata hasil belajar siswa sebesar 70,25 kategori cukup. Pada siklus I menunjukkan kemajuan dari refleksi awal. Nilai rata-rata prestasi belajar siswa mengalami peningkatan yaitu $55,00 \%$. Secara klasikal siswa yang telah mencapai ketuntasan belajar sebesar 55,00\% (11 orang) dari 20 orang siswa. Jika diinterpretasikan hasil belajar pada siklus I bahwa penerapan Model Pembelajaran Kooperatif Tipe Jigsaw sudah menunjukkan hasil yang meningkat namun belum optimal karena peningkatan daya serap siswa terhadap materi pembelajaran masih kurang. Hal tersebut disebabkan oleh banyak faktor baik internal maupun eksternal siswa terutama belum terbiasanya siswa mengikuti pembelajaran dengan formulasi yang diterapkan guru. 
Hal tersebut menyebabkan penguasaan siswa terhadap materi pokok pembelajaran belum optimal.

Hasil penelitian pada siklus I yang menunjukkan bahwa terjadi peningkatan pada nilai rata-rata hasil belajar menjadi kategori cukup, dan ketuntasan klasikal $55 \%$ berarti belum mampu mencapai kriteria keberhasilan yang telah ditetapkan yaitu $85 \%$. Hipotesis tindakan yang berbunyi : penerapan model pembelajaran kooperatif tipe Jigsaw secara signifikan dapat meningkatkan prestasi belajar siswa kelas XI IPA 4 SMA Negeri 1 Selemadeg tahun pelajaran 2014/2015 belum bisa diterima. Oleh karena itu, penelitian harus dilanjutkan ke siklus II.

Setelah dilaksanakan tindakan pada siklus II diperoleh hasil sebagai berikut, seperti pada Tabel 3 .

Tabel 3. Data Hasil Belajar Siswa pada Siklus II

\begin{tabular}{|l|l|r|r|l|}
\hline No & Keaktifan dan Hasil Belajar & Rata-rata & Persentase & Kategori \\
\hline 1. & Ketuntasan Individu ( KI) & & & \\
& Tuntas (17 orang) & - & $85,00 \%$ & \\
& Tidak tuntas (3 orang) & - & $15,00 \%$ & \\
2. & Nilai rata-rata hasil belajar & 81,25 & & Baik \\
3. & Ketuntasan Klasikal (KK) & -- & $85,00 \%$ & Tuntas \\
\hline
\end{tabular}

Setelah dilaksanakan perbaikan tindakan pada pelaksanaan siklus II dengan melakukan kontrol/pengawasan dan layanan konsultatif yang lebih intensif ketika proses pembelajaran berlangsung, menunjukkan adanya peningkatan hasil belajar siswa dalam prestasi belajarnya.

Berdasarkan hasil penelitian sebagaimana tertuang dalam Tabel 3 dapat diinterpretasikan bahwa rerata nilai hasil belajar mengalami peningkatan dari siklus I sebesar 70,25 menjadi 81,25 pada siklus II, dengan ketuntasan klasikal sebesar 55,00 \% pada siklus I menjadi 85,00 siklus II.

Meningkatnya prestasi belajar siswa pada siklus II karena pada siklus II pembelajaran sudah mencerminkan model pembelajaran tipe Jigsaw di mana siswa sudah mampu mengikuti formulasi pembelajaran yang dimaksudkan guru. Berdasarkan analisis data tersebut dapat disimpulkan bahwa hasil penelitian pada siklus II telah dapat mencapai kriteria keberhasilan yang telah ditetapkan.

Sebagai gambaran untuk menunjukkan adanya hubungan antarsiklus dalam penelitian tindakan ini disajikan rekapitulasi data prestasi belajar siswa pada refleksi awal dan siklus I dapat disajikan pada Tabel 4. 
Tabel 4. Rekapitulasi Prestasi Belajar dan Persentase Ketuntasan Belajar Siswa pada Refleksi Awal dan Siklus I

\begin{tabular}{|l|l|l|l|l|}
\hline No & Hasil Belajar & Refleksi Awal & Siklus I & Peningkatan \\
\hline 1. & Ketuntasan Individu (KI) & & & \\
& a. Tuntas & $30,00 \%$ & $55,00 \%$ & $25 \%$ \\
& b. Tidak Tuntas & $70,00 \%$ & $45,00 \%$ & \\
2. & Nilai rata-rata hasil belajar & 63,75 & 70,25 & 6,50 \\
3. & Daya Serap (DS) & $63,75 \%$ & $70,25 \%$ & $6,50 \%$ \\
4. & Ketuntasan Klasikal (KK) & $30,00 \%$ & $55,00 \%$ & $25 \%$ \\
\hline
\end{tabular}

Dari tabel rekapitulasi hasil belajar siswa pada refleksi awal dan siklus I, mengalami cukup banyak peningkatan. Ketuntasan individu dan ketuntasan klasikal meningkat sebesar $25 \%$. Sedangkan nilai rata-rata hasil belajarnya meningkat sebanyak $6,50 \%$.

Rekapitulasi data mengenai hasil belajar siswa pada siklus I dan siklus II dapat disajikan pada Tabel 5 .

Tabel 5. Rekapitulasi Prestasi Belajar Siswa pada Siklus I dan Siklus II

\begin{tabular}{|l|l|c|c|c|}
\hline No & Hasil Belajar & Siklus I & Siklus II & Peningkatan \\
\hline 1. & Ketuntasan Individu (KI) & & & \\
& a.Tuntas & $55,00 \%$ & $85,00 \%$ & $30,00 \%$ \\
& b.Tidak Tuntas & $45,00 \%$ & $15,00 \%$ & \\
\hline 2. & Nilai rata-rata hasil belajar & 70,25 & 81,25 & 11,00 \\
\hline 3. & Daya Serap (DS) & $70,25 \%$ & $81,25 \%$ & $11,00 \%$ \\
\hline 4. & Ketuntasan Klasikal (KK) & $55,00 \%$ & $85,00 \%$ & $30,00 \%$ \\
\hline
\end{tabular}

Dari data tabel rekapitulasi prestasi belajar siswa pada siklus I dan siklus II, cukup banyak mengalami peningkatan, ketuntasan individu dan ketuntasan klasikalnya meningkat sebesar $30,00 \%$. Sedangkan nilai rata-rata hasil belajar mengalami peningkatan sebesar $11,00 \%$. Dalam siklus II siswa yang tuntas sebanyak 17 orang dan 3 orang siswa tidak tuntas dari 20 orang siswa.

Rekapitulasi data mengenai prestasi belajar siswa (ketuntasan individu, nilai ratarata belajar, daya serap dan ketuntasan klasikal) pada refleksi awal, siklus I dan siklus II dapat disajikan pada Tabel 6 . 
Tabel 6. Rekapitulasi Prestasi Belajar Siswa pada Refleksi Awal, Siklus I dan Siklus II

\begin{tabular}{|l|l|l|c|c|}
\hline No & \multicolumn{1}{|c|}{ Hasil Belajar } & $\begin{array}{c}\text { Refleksi } \\
\text { Awal }\end{array}$ & Siklus I & Siklus II \\
\hline 1. & Ketuntasan Individu (KI) & & & \\
& a. Tuntas $\quad$ Tidak Tuntas & $70,00 \%$ & $45,00 \%$ & $15,00 \%$ \\
\hline 2. & Nilai rata-rata hasil belajar & 63,75 & 70,25 & 81,25 \\
\hline 3. & Daya Serap (DS) & $63,75 \%$ & $70,25 \%$ & $81,25 \%$ \\
\hline 4. & Ketuntasan Klasikal (KK) & $30,00 \%$ & $55,00 \%$ & $85,00 \%$ \\
\hline
\end{tabular}

Jika divisualisasikan dalam bentuk grafik, maka perbandingan rata-rata prestasi belajar siswa antara refleksi awal, siklus I dan siklus II tampak seperti Gambar 1.

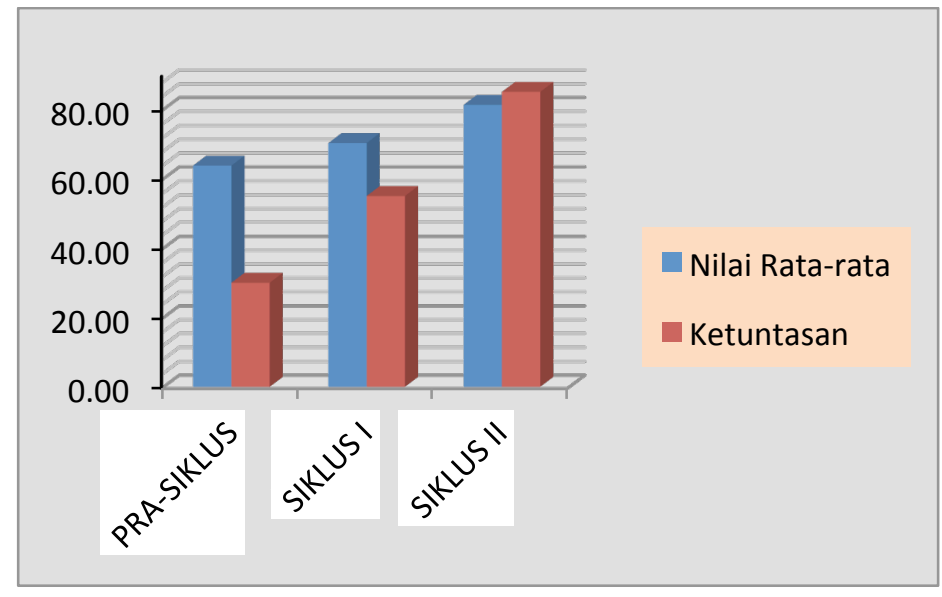

Gambar 1. Peningkatan Rata-rata Prestasi Belajar Siswa

Dari hasil analisis data diketahui bahwa ada perbedaan prestasi belajar siswa sebelum diberikan tindakan dan sesudah diberi tindakan dengan penerapan model pembelajaran kooperatif tipe Jigsaw. Setelah diberikan tindakan terjadi perubahan suasana kelas dari sebelumnya. Suasana pembelajaran lebih kondusif, siswa lebih fokus dalam mengikuti kegiatan pembelajaran.

Penelitian tindakan ini berimplikasi positif bagi guru dan siswa. Bagi guru akan lebih memudahkan dalam mentransformasi pengetahuan dan keterampilan dalam proses pembelajaran. Di samping itu, inovasi dan kreativitasnya dapat dikembangkan sesuai dengan tuntutan profesionalisme guru saat ini khususnya dalam kompetensi pedagogik. 
Melalui penelitian tindakan ini akan berimplikasi langsung terhadap siswa karena siswa dapat ruang dan peluang yang lebih terbuka dalam mengembangkan kompetensi dan kreativitasnya.

Jadi, penelitian tindakan yang berjudul : Penerapan Model Pembelajaran Kooperatif tipe Jigsaw dapat meningkatkan Prestasi Belajar Fisika Siswa Kelas XI IPA. 4 SMA Negeri 1 Selemadeg Tahun Pelajaran 2014/2015

\section{SIMPULAN}

Berdasarkan hasil penelitian yang dilaksanakan melalui tiga tahapan, yaitu: prasiklus, siklus I, dan siklus II yang mana masing-masing tahapan dilakukan tiga kali tindakan, maka dapat disimpulkan hal-hal sebagai berikut.

Capaian nilai rata-rata prasiklus sebesar 63,75 dan ketuntasan belajar sebesar $30,00 \%$ termasuk kategori sangat kurang, kemudian mengalami peningkatan pada tindakan siklus I dengan capaian nilai rata-rata sebesar 70,25 dan ketuntasan belajar sebesar 55,00\% termasuk kategori sangat kurang, selanjutnya mengalami peningkatan yang sangat signifikan pada tindakan siklus II dengan capaian nilai rata-rata sebesar 81,25 dan persentase ketuntasan sebesar 85,00 tergolong kategori baik, maka berarti penerapan model pembelajaran kooperatif tipe Jigsaw dapat meningkatkan prestasi belajar Fisika siswa Kelas XI IPA 4 SMA Negeri 1 Selemadeg tahun pelajaran 2014/2015.

\section{DAFTAR PUSTAKA}

Depdiknas.2006. Petunjuk Teknis Pengembangan Silabus dan Contoh/ Model Silabus.Mata Pelajaran:Fisika. SMA/MA. Jakarta. BNSP. Haryanto.2010.Pengertian Prestasi Belajar. Tersedia pada :

http://belajarpsikologi.com/pengertian-prestasi-belajar/. Diakses pada 15 Januari 2015

Rusman. 2008. Pembelajaran Jigsaw. Jakarta: Bumi Aksara 
